\title{
2D and 3D Ultrasonographic Evaluation of Fetal Midface Hypoplasia in Two Cases with 3-M Syndrome
}

\section{2-D- und 3-D-Sonografie zur Evaluierung von fetaler Mittelgesichtshypoplasie in 2 Fällen mit 3M-Syndrom}

Authors

Affiliation
A. Vimercati, A. Chincoli, A. C. de Gennaro, V. D’Addario, E. Cicinelli

Department of Biomedical and Human Oncological Science (DIMO), 2nd Unit of Obstetrics and Gynecology, University of Bari, Bari, Italy

\author{
Key words \\ - fetal midface hypoplasia \\ - 3-M syndrome \\ - prenatal diagnosis \\ - ultrasound \\ Schlüsselwörter \\ - fetale Mittelgesichts- \\ hypoplasie \\ - 3M-Syndrom \\ - Pränataldiagnostik \\ - Sonografie
}

$\begin{array}{ll}\text { received } & 23.10 .2015 \\ \text { revised } & 16.3 .2016 \\ \text { accepted } & 20.3 .2016\end{array}$

Bibliography

Dol http://dx.doi.org/

10.1055/s-0042-105285

Geburtsh Frauenheilk 2016; 76:

814-818 @ Georg Thieme

Verlag KG Stuttgart · New York . ISSN 0016-5751

\section{Correspondence}

Dr. Annarosa Chincoli

University of Bari

Department of Biomedical

and Human Oncological Science

(DIMO)

2nd Unit of Obstetrics

and Gynecology

Piazza Giulio Cesare

70124 Bari

Italy

annarosa.chincoli@virgilio.it

\section{Abstract \\ $\nabla$}

This paper highlights the utility of 2D and 3D ultrasonography in the prenatal diagnosis of facial dysmorphisms suggestive of very rare syndromes such as 3-M syndrome. Two pregnant women at risk for fetal skeletal dysplasias were referred to our clinic for $2 \mathrm{D} / 3 \mathrm{D}$ ultrasound scan in the second trimester of pregnancy. Only one of the patients had a familial history of 3-M syndrome. Karyotyping and genetic testing of abortion material were performed in both cases. 2D ultrasonography revealed growth retardation of the long bones in both cases. In the case without a familial history of the syndrome, 2D and 3D ultrasonography showed an absence of nasal bones and a flat malar region suggestive of 3-M syndrome, although the difficult differential diagnosis included other dysmorphic growth disorders with prenatal onset. The karyotype was normal but the pregnancy was terminated in both cases. Postmortem examination confirmed 3-M syndrome as indicated by prenatal findings. In high-risk cases with a familial history of 3-M syndrome, prenatal diagnosis of 3-M syndrome is possible by analyzing fetal DNA. In the absence of risk, a definitive prenatal diagnosis is often not possible but may be suspected in the presence of shortened long bones, normal head size and typical flattened malar region (midface hypoplasia) shown on complementary 2D and 3D sonograms. 2D and 3D ultrasonography has been shown to offer reliable information for the prenatal study of skeletal and facial anomalies and can be useful if there is a suspicion of 3-M syndrome in a pregnancy not known to be at risk.

\section{Zusammenfassung \\ $\nabla$}

Es wird hier auf die Bedeutung von 2-D- und 3-DSonografie hingewiesen in der Pränataldiagnostik von Gesichtsdysmorphien, die auf sehr seltene Syndrome wie das 3M-Syndrom hindeuten. Zwei schwangere Frauen, bei denen die Vermutung einer fetalen Skelettdysplasie bestand, wurden im 2. Trimenon an unsere Abteilung überwiesen zwecks Abklärung mittels 2-D- und 3-D-Sonografie. Nur eine der Patientinnen hatte eine Familienanamnese für 3M-Syndrom. In beiden Fällen wurden eine Karyotypisierung sowie eine genetische Analyse des Abortmaterials durchgeführt. Die 2D-Sonografie wies bei beiden Feten eine Wachstumsretardierung der langen Röhrenknochen nach. Im Fall ohne familiäre Vorbelastung zeigte die Abklärung mittels 2-D- und 3-D-Ultraschall ein fehlendes Nasenbein und eine fetale Mittelgesichtshypoplasie, was auf 3M-Syndrom hindeutete. Die schwierig zu stellende Differenzialdiagnose schloss auch andere dysmorphe Wachstumsstörungen mit vorgeburtlichem Beginn mit ein. Der Karyotyp war normal, aber in beiden Fällen wurde die Schwangerschaft abgebrochen. Die Obduktion bestätigte die auf der pränatalen Untersuchung basierende Diagnose eines 3M-Syndroms. Bei Hochrisikopatientinnen mit 3M-Syndrom in der Familiengeschichte ist eine vorgeburtliche Diagnose des 3M-Syndroms durch eine Analyse der fetalen DNA möglich. Besteht kein familiäres Risiko, ist eine eindeutige vorgeburtliche Diagnose oft nicht möglich, aber Befunde wie verkürzte Röhrenknochen, normale Kopfgröße und fetale Mittelgesichtshypoplasie bei der komplementär durchgeführten 2-D- und 3-D-Sonografie können auf 3M-Syndrom hinweisen. Die 2-D- und 3-D-Sonografie liefern zuverlässige Informationen für die vorgeburtliche Evaluierung von Skelett- und Gesichtsanomalien und eignen sich gut zur Abklärung bei Verdacht auf 3M-Syndrom. 

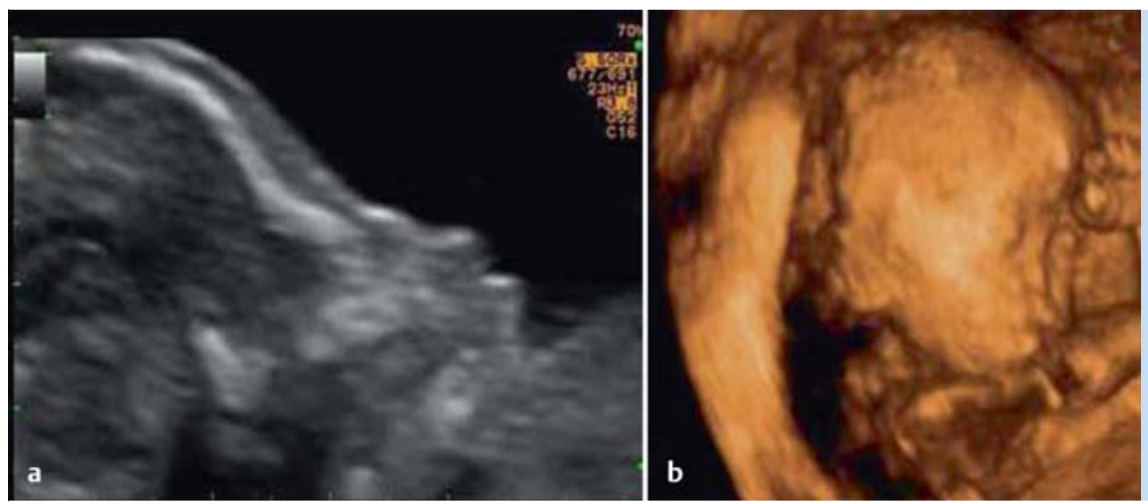

Fig. $1 \mathbf{a}$ and $\mathbf{b}$ Midface hypoplasia with flattened malar region detected on $2 \mathrm{D}(\mathrm{a})$ and $3 \mathrm{D}$ ultrasonography (b) in case 2 .

\section{Introduction}

$\nabla$

3-M syndrome is a rare form of autosomal recessive dwarfism characterized by severe pre- and postnatal growth retardation (final height: 5-6 SD below the mean, i.e., 120-130 cm), characteristic facies, and normal intelligence. It is a rare syndrome and its prevalence is unknown; approximately 100 affected individuals have been reported in the literature since the first case was described in 1975 [1,2]. A diagnosis of 3-M syndrome may be suggested in children with low birth weight, characteristic facies, and radiological findings that may not be present in the first two years of life. Molecular genetic testing is useful to confirm the diagnosis: CUL7, OBSL1 and CCDC8 are the only genes with mutations known to cause 3-M syndrome. However, it is difficult to make the diagnosis prenatally, especially in the absence of a familial history. This is due to the fact that, although the most striking feature of 3-M syndrome is severe growth retardation starting in utero, intrauterine growth retardation is not specific and the skeletal findings only appear after birth. We report on two cases with prenatal findings suspicious for 3-M syndrome with and without a familial history of the syndrome. Both pregnancies ended with termination of pregnancy (TOP) [3].

\section{Case Reports}

\section{Patient 1}

L. S., a 34-year-old woman, was referred to us in her 18th week of pregnancy for an anatomical survey ultrasound scan. She is married to her first cousin. Her first pregnancy led to a child with 3-M syndrome and her second pregnancy was terminated following a prenatal diagnosis of Down syndrome (previously published case) [3].

Screening of chromosomopathies was done at 12 weeks' gestation. Findings were negative, and nuchal translucency values were within normal ranges. At 18 weeks' gestation, ultrasound assessment showed a single fetus with a biparietal diameter and a head circumference of $45 \mathrm{~mm}$ and $125 \mathrm{~mm}$ respectively, which was appropriate for gestational age. The respective femur and tibia lengths were 22.4 and $19.6 \mathrm{~mm}$, which corresponds to the fifth centile for gestational age, while the radius, ulna and humeral lengths were 17.6, 17.6 and $20.8 \mathrm{~mm}$, respectively, which were all below the fifth centile. The amniotic fluid was normal. A further scan for amniocentesis and to monitor long bone growth was performed at 22 weeks' gestation. The karyotype was normal (46XY) and the biparietal diameter, head circumference and head shape were normal. However, measured femur, tibia, fibula, hu-

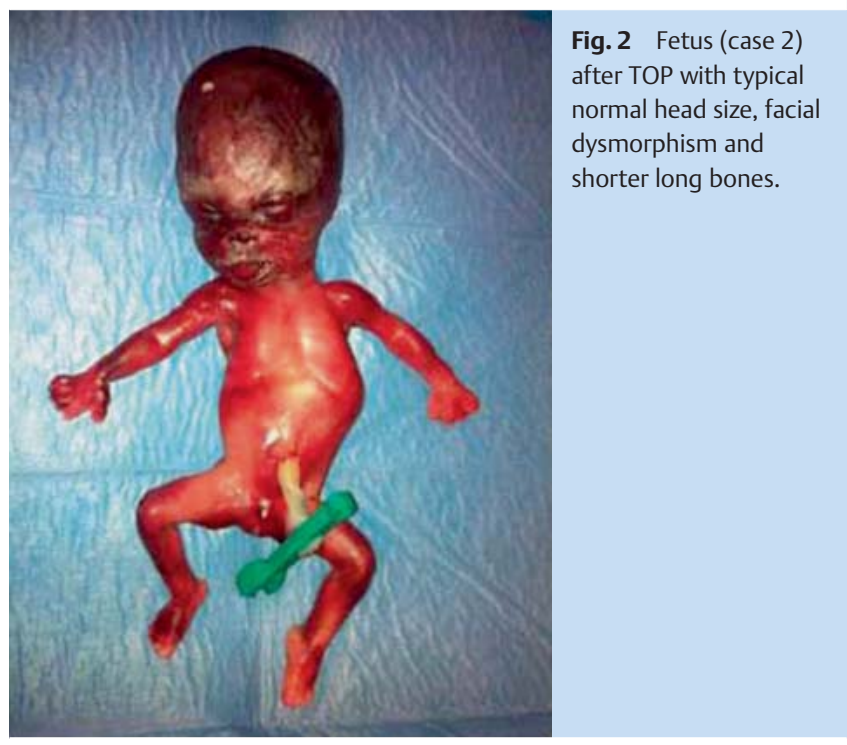

meral, radius and ulna lengths were 28, 24, 25, 28, 24 and $25 \mathrm{~mm}$, respectively. The thorax showed mild hypoplasia (short thorax with normal circumference), and mild polyhydramnios was present. In view of these findings and, in particular, of the patient's previous history, a diagnosis of 3-M syndrome was made. The pregnancy was terminated shortly thereafter. The postmortem examination findings were consistent with the prenatal signs and featured short long bones, a normal-sized head and a short thorax. Finally, genetic testing confirmed 3-M syndrome with CUL7 gene defect.

\section{Patient 2}

L. M., a 30-year-old Caucasian woman, was referred to us for evaluation in her second trimester of pregnancy. The pregnancy, which was her first, started as a twin pregnancy. However, the patient miscarried one fetus at 9 weeks' gestation. She has no familial history of 3-M syndrome.

Nuchal translucency measured at 11 weeks of gestation was normal. Ultrasound assessment at 16 weeks' gestation showed a biparietal diameter, head circumference, abdominal circumference and femur length of $35 \mathrm{~mm}, 14.6 \mathrm{~cm}, 9.4 \mathrm{~cm}$, and $2 \mathrm{~cm}$, respectively, which were in accordance with gestational age. Another scan was performed at 22 weeks' gestation to evaluate fetal morphology. The results confirmed that biparietal diameter and head circumference were normal for gestational age, measuring $53.5 \mathrm{~mm}$ and $18.6 \mathrm{~cm}$, respectively. The lengths of the long bones 
Table 1 Useful pointers to guide clinicians through the differential aspects of IUGR syndrome.

\begin{tabular}{|c|c|c|c|c|c|}
\hline & 3-M syndrome & $\begin{array}{l}\text { Silver-Russell } \\
\text { syndrome (SRS) }\end{array}$ & $\begin{array}{l}\text { Mulibrey } \\
\text { nanism }\end{array}$ & $\begin{array}{l}\text { Dubowitz } \\
\text { syndrome }\end{array}$ & $\begin{array}{l}\text { Fetal alcohol } \\
\text { syndrome }\end{array}$ \\
\hline IUGR & $\checkmark$ & $\checkmark$ & $\checkmark$ & $\checkmark$ & $\checkmark$ \\
\hline Triangular face & $\checkmark$ & $\checkmark$ & $\checkmark$ & & \\
\hline Microcephaly & & & & $\checkmark$ & $\checkmark$ \\
\hline Mental retardation & & $\checkmark$ & & $\checkmark$ & $\checkmark$ \\
\hline Flattened malar region & $\checkmark$ & & $\checkmark$ & & \\
\hline Short long bones & $\checkmark$ & $\checkmark$ & $\checkmark$ & & \\
\hline Limb length asymmetry & & $\checkmark$ & & & \\
\hline Maternal alcoholism & & & & & $\checkmark$ \\
\hline
\end{tabular}

length were, however, below the fifth centile: ulna: $22.7 \mathrm{~mm}$; fibula: $20.5 \mathrm{~mm}$; humerus: $20.5 \mathrm{~mm}$; radius: $22 \mathrm{~mm}$; tibia: $20.8 \mathrm{~mm}$; femur: $21 \mathrm{~mm}$. Amniotic fluid was normal, but umbilical artery Doppler flow was pathologic with an absence of diastolic waves. The 2- and 3-dimensional ultrasound evaluations of the fetal face profile both showed an absence of nasal bones, a flattened malar region ( $\bullet$ Fig. 1), and a left club foot. The karyotype was assessed by chorionic villus sampling at 22 weeks' gestation and was found to be normal (46XX).

The ultrasound findings suggested a diagnosis of 3-M syndrome, and genetic testing was proposed. After TOP, small pieces of fetal skin and placenta were taken for molecular genetic testing. The fetus was characterized by severe growth retardation, hypoplastic midface, absent nasal bone, short long bones with flared metaphyses, and left club foot ( Fig. 2). The placenta showed dissociative growth of the chorionic villi with numerous syncytial knots and intervillous lacuna constriction. The anthropologist and pathologist who analyzed the histological and clinical features considered the findings to be strongly suspicious for 3-M syndrome; genetic testing subsequently confirmed CUL7 mutation.

\section{Discussion \\ $\nabla$}

3-M syndrome is a rare entity characterized by severe growth retardation, skeletal changes including slender tubular bones and tall vertebral bodies, and a distinctive facial dysmorphism which involves triangular facies, frontal bossing, midface hypoplasia, fleshy tipped nose, short thorax and square shoulders as its major components $[4,5]$. Both sexes are equally affected; individuals with 3-M syndrome have normal intelligence. No microcephaly or hormonal deficiencies have been associated with 3-M syndrome. Males with 3-M syndrome have hypogonadism and, occasionally, hypospadias.

3-M syndrome is an autosomal recessive condition, and prenatal testing in pregnancies at increased risk is possible. CUL7, OBSL1 and CCDC8 are the only genes where mutations are known to cause 3-M syndrome.

The precise mechanism of prenatal and postnatal growth retardation in 3-M syndrome remains unclear. Based on an analysis of mice with disruption of the CUL7 gene, it has been speculated that CUL7 affects vasculogenesis or angiogenesis. Due to the mutation, the number of villi in the placenta was markedly increased in the fetus. The imbalance in the number of fetal and maternal blood vessels may underpin the mechanism of prenatal growth retardation in 3-M syndrome. The role of OBSL1 in growth has not been recognized, but loss of OBSL1 by siRNA knockdown leads to concomitant loss of CUL7 [6].
After birth, it is possible to establish a diagnosis of 3-M syndrome based on clinical and radiographic findings that may not be present in the first two years of life. These findings include slender long bones with diaphyseal constriction and flared metaphyses, tall vertebral bodies that become foreshortened over time, anterior wedging of thoracic vertebral bodies, thoracic kyphoscoliosis, small pelvic bones, and a broad thorax with slender and horizontal ribs. During pregnancy, however, the diagnosis of 3-M syndrome is rarely suspected, as prenatal ultrasound examination usually reveals severe growth retardation of all long bones, as shown in the two cases reported here, which is not an unequivocal sign of the disorder.

Intrauterine growth retardation (IUGR) is the main characteristic of a large group of other growth retardation-malformation syndromes. Thus, it is very important to distinguish 3-M syndrome from other forms of IUGR, such as Silver-Russell syndrome (SRS), Mulibrey nanism, Dubowitz syndrome and fetal alcohol syndrome.

SRS has many similarities to 3-M syndrome, including intrauterine growth retardation, short stature, triangular face, relatively large skull, asymmetry of body or limbs, and clinodactyly. Mild mental retardation may also be found in patients with SRS [4]. However, the characteristic radiological findings of 3-M syndrome are not found in Silver-Russell syndrome. Chromosomes 11 and 17 have been found to be consistently involved in individuals fulfilling the strict diagnostic criteria of SRS [7].

Mulibrey nanism is a disorder characterized by prenatal and postnatal growth deficiencies, relatively large hands, triangular facies with depressed nasal bridge and small tongues. At birth, individuals with Mulibrey nanism are usually not as small as neonates with 3-M syndrome. The facial features are also different, with affected individuals having a high forehead and pseudo-hydrocephalic skull configuration. Molecular genetic testing of TRIM37, the gene whose mutations cause the disorder, can be used to differentiate Mulibrey nanism from 3-M syndrome [8]. Microcephaly, eczema, a characteristic facial appearance, and intellectual disability are the main features differentiating Dubowitz syndrome from 3-M syndrome.

A history of maternal alcoholism is usually present in individuals with fetal alcohol syndrome; microcephaly, nail hypoplasia, a specific facial appearance, and intellectual disability are the primary differences. It can be challenging to discriminate between these disorders because they are rare and, as discussed above, many ultrasound findings are not necessarily pathognomonic for a specific disorder. Obtaining a differential diagnosis before delivery is very useful for clinical decision making and to accurately determine the risk of recurrence. In families at risk for this syndrome, prenatal diagnosis is possible by analyzing the DNA 

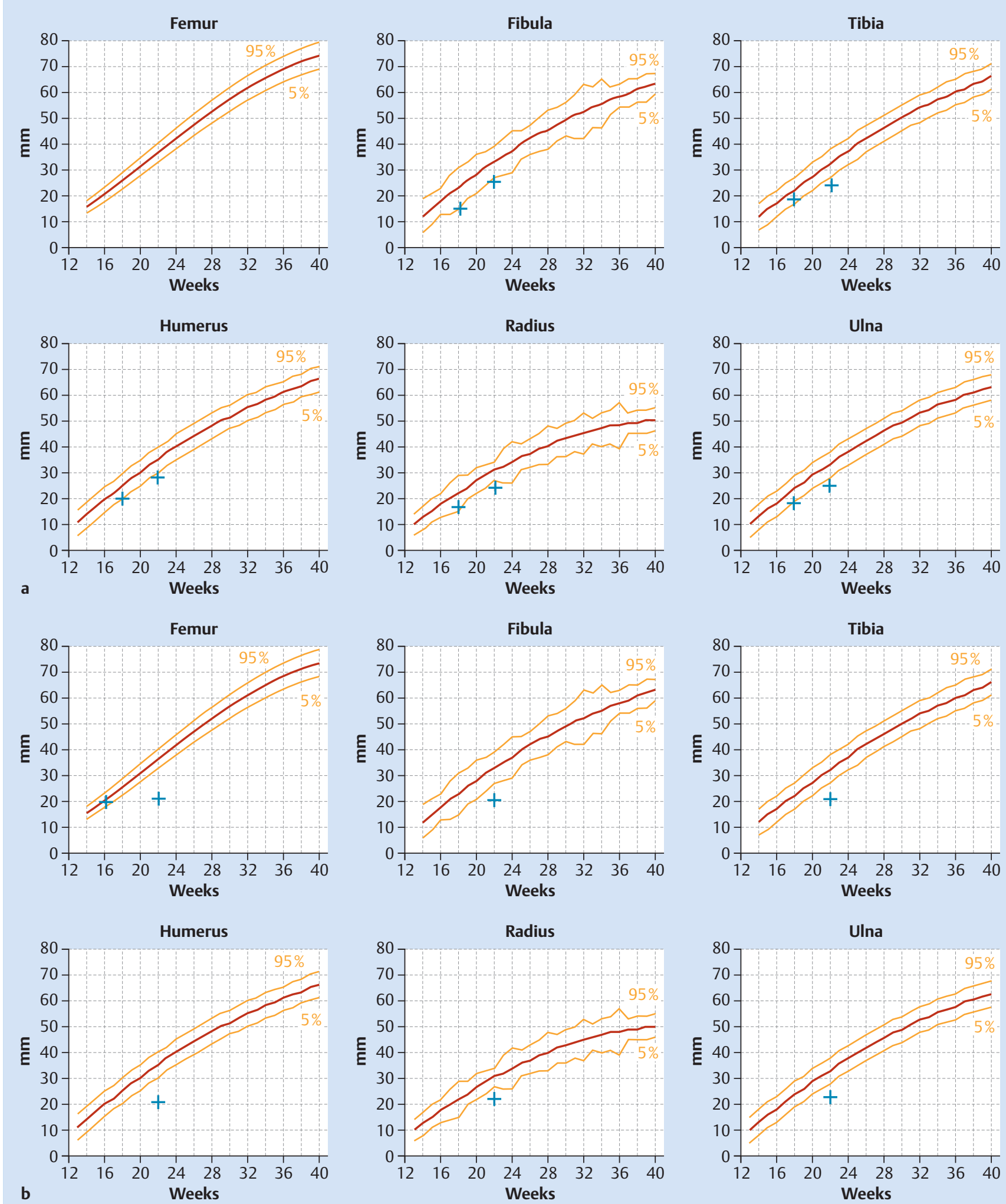

Fig. 3 a and $\mathbf{b}$ Fetal limb growth curves (5th, 50th, 95th centiles): long bone growth was already below or equal to the fifth centile. a Case 1 . b Case 2. Curves are based on [10].

extracted from fetal cells obtained by amniocentesis or chorionic villus sampling (CVS). O Table 1 can guide clinicians through the differential aspects of mid facial hypoplasia and IUGR syndrome.
In the two cases described in this paper, the nasal bones could not be visualized and long bone growth was already below or equal to the fifth centile at 18 and at 22 weeks' gestation (O Fig. 3). 
Facial dysmorphisms and anomalies involving the hands and feet may be visualized better with 3D ultrasonography, as demonstrated in case 2 who had no familial history. Three-dimensional ultrasonography is currently accepted as an interesting complementary technique to conventional 2D ultrasonography in the antenatal diagnosis of skeletal dysplasia [9].

3D ultrasonography can be used to visualize planes of section that cannot be obtained with 2D ultrasonography, allowing a comprehensive evaluation of fetal facial anatomy, with visualization of all facial structures such as the fetal nose, eyebrows, mouth and eyelids. One of the most important advantages of 3D ultrasonography is its ability to display a true midsagittal plane of the fetal face.

\section{Conclusion}

$\nabla$

Prenatal diagnosis of 3-M syndrome is very important to establish a prognosis and perform molecular genetic testing to confirm the diagnosis and provide parents with information on the nature and implications of this genetic disorder [9]. 2D and 3D ultrasonography have been shown to be reliable in the prenatal study of skeletal and facial anomalies and can be useful if there is a suspicion of 3-M syndrome in a pregnancy not known to be at risk.

\section{Conflict of Interest}

The authors declare that they have no conflicts of interest.

\section{References}

1 Camera G, Mastroiacovo P. Birth prevalence of skeletal dysplasias in the Italian multicentric monitoring system for birth defects. Prog Clin Biol Res 1982; 104: 441-449

2 Miller JD, McKusick VA, Malvaux P et al. The 3-M syndrome: a heritable low birthweight dwarfism. Birth Defects Orig Artic Ser 1975; 11: 3947

3 Meo F, Pinto V, D'Addario V. 3-M syndrome: a prenatal ultrasonographic diagnosis. Prenat Diagn 2000; 20: 921-923

4 Güven A, Cebeci NA. 3M syndrome: a report of four cases in two families. J Clin Res Pediatr Endocrinol 2011; 3: 154-159

5 Van der Wal G, Otten BJ, Brunner HG et al. 3-M syndrome: description of six new patients with review of the literature. Clin Dysmorphol 2001; 10: 241-252

6 Hanson D, Murray PG, O'Sullivan J et al. Exome sequencing identifies CCDC8 mutations in 3-M syndrome, suggesting that CCDC8 contributes in a pathway with CUL7 and OBSL1 to control human growth. Am J Hum Genet 2011; 89: 148-153

7 Eggermann T, Begemann M, Binder G et al. Silver-Russell syndrome: genetic basis and molecular genetic testing. Orphanet J Rare Dis 2010; 5: 19

8 Avela K, Lipsanen-Nyman M, Idänheimo $N$ et al. Gene encoding a new RING-B-box-Coiled-coil protein is mutated in mulibrey nanism. Nat Genet 2000; 25: 298-301

9 Cassart M. Suspected fetal skeletal malformations or bone diseases: how to explore. Pediatr Radiol 2010; 40: 1046-1051

10 Snijders RJ, Nicolaides KH. Fetal biometry at 14-40 weeks' gestation. Ultrasound Obstet Gynecol 1994; 4: 34-48 